\title{
Social Cash Transfers and Children's Rights in Zambia ${ }^{i}$
}

\author{
David S. Chibanda
}

University of Roehampton, London, United Kingdom

Copyright $\bigcirc 2019$ by authors, all rights reserved. Authors agree that this article remains permanently open access under the terms of the Creative Commons Attribution License 4.0 International License

\begin{abstract}
Social cash transfers are gaining momentum within developing countries, including Zambia. Cash transfers are income support payments given to vulnerable households to reduce extreme poverty and promote children's education, health and nutrition. Since 2004, Zambia has been implementing cash transfers. A number of studies have concluded that cash transfers have helped reduce poverty among poor households in the country. This study assesses the extent to which cash transfers in Zambia have impacted on poverty reduction and children's rights. The study concludes that, while there is evidence that cash transfers have helped to reduce poverty and improve children's access to social services, their effective implementation remains constrained by administrative, coordination, and capacity challenges, as well as lack of a defined long-term financial commitment.
\end{abstract}

Keywords Poverty, Social Protection, Social Cash Transfers, Children's Rights, Zambia

\section{Introduction}

Social cash transfers are cash payments given to vulnerable individuals and households to reduce extreme poverty and promote children's rights, particularly the right to education, health, and nutrition. Cash transfers are "best implemented as rights-based entitlements that express the social contract between citizen and state, rather than as a welfare response to need." (Richter, 2009). Cash transfers differ from welfare payments paid in Western liberal democracies in that as cash payments, they are inexpensive and offer the intended beneficiaries the freedom to do what they wish to do with the money. In other words, cash allows those in need to meet their needs more specifically. This rationale is premised on the theory that it is only beneficiaries that know well their needs and how best to fulfil them in the best way they can. Cash transfers also eliminate costs associated with the distribution of goods and services the donor incurs in the provision of welfare or in-kind benefits. In this way, it would be legitimate to argue that cash transfers are more efficient than welfare payments. However, the disadvantage of cash transfers is that not all beneficiaries would spend the cash wisely or prudently, and priorities differ markedly among them. For example, a drug addict would rather spend the cash payment on alcohol at the expense of food or other necessaries which might be more beneficial to his wellbeing. This is why others would give a needy person food rather than cash. Cash transfers are also susceptible to corruption and theft, particularly by those tasked with managing them and this subsequently deprives their intended beneficiaries. In addition, transporting money is a very risky undertaking and accessing it can be a challenge for beneficiaries living in remote areas who have to cover distances to access the funds.

In contrast, welfare payments are paid - usually through tax payers, NGOs, and charities - to the unemployed, persons with illness or disability, the elderly, those with dependent children, and so on, in a variety of forms such as monetary payments, free or subsidized supply of goods and social services such as healthcare, education, housing, and skills training to enable them attain a minimum level of well-being (Bullock \& Trombley, 1999). Welfare payments are a distinctive feature of the welfare state-a political arrangement where the government takes responsibility to provide health, education, and welfare of society. Welfare payments allow the donor or government much control on the resources given to beneficiaries. By determining, for example, that a beneficiary gets food, clothing, or other in-kind benefits, the donor is at least assured that the beneficiary will get exactly the type of assistance the donor meant to give. The downside of this kind of assistance, however, is the logistical challenge it creates; delivering goods require transportation and storage and these attract costs. Moreover, goods such as food and medicines can only be stored for a limited period of time before they lose their merchantable quality. This attracts additional expenses for the donor. The other problem with welfare payments is that they do not offer the flexibility social cash transfers give beneficiaries and may not be ideal for them. For example, a beneficiary may opt for cash in order to buy uniforms or pay school fees for a child, rather than food handouts, which may limit their ability to determine precisely what their real needs are at a particular 
time.

Studies by other researchers have concluded that cash transfers enable poor families become food secure and generate investment and increase children's access to education and health services, which subsequently prevents child labour (Seidenfeld et al., 2013; Seidenfeld \& Handa, 2011). It is thus argued that this ultimately improves children's living conditions in developing countries. Similarly, a number of evaluation studies in many including Zambia have consistently reported positive impacts of cash transfers on targeted households. However, most of these studies, commissioned by implementing or funding agencies, often have particular beliefs intended to support certain policies and programmes (Chinsinga, 2009; Schubert, 2005).

This study sought to critically assess the extent to which social cash transfers have impacted on poverty reduction and children's rights in Zambia. Specific study aims were: (i) explore people's perception and understanding of cash transfers; (ii) investigate how cash transfers had contributed to poverty reduction and improved children's education, health, and nutrition; (iii) assess whether cash transfers are sustainable; and, (iv) identify challenges affecting the social cash transfer programme in Zambia.

This paper is divided into seven sections. Section 1 gives a brief introduction and research context underpinning the study, while Section 2 examines the concept of poverty in global context. Section 3 discusses the use of social protection as a poverty reduction strategy. The study's research methods, data analysis techniques, study rationale, and research limitations are explained in Section 4, and Section 5 provides an overview of the policy and legal context of social cash transfers and children's rights in Zambia. Section 6 presents and discusses the study's key findings. Finally, Section 7, the conclusion, restates the argument, based on study findings, that while social cash transfers have had positive outcomes on children's rights in Zambia, their effective implementation is nonetheless constrained by a number of challenges.

\section{Poverty in Global Context}

Before assessing the impact of social cash transfers on children's rights in Zambia it is imperative first to examine the concept of poverty because any meaningful discussion on social cash transfers and children's rights requires an understanding of poverty and the politics of social protection. This is because poverty is one of the major social problems facing developing countries including Zambia. Poverty retards human development and significantly constrains children's access to basic social services and opportunities (World Bank, 2012: 11-13). For this reason, poverty reduction remains one of the key objectives of international development and a major focus of the Sustainable Development Goals (World Bank, 1990;
UNDP, 2014a; UNDP, 2014b). Political economists view the world as a world of problems and poverty, particularly child poverty, stands out as a reflection of the failure of the international system (Allen \& Thomas, 2000). Moreover, global wealth distribution is consistently unequal, particularly between the affluent, industrialized North and the developing South (UNDP, 2014a: 164-168) and children from poor households especially in developing countries tend to be among the most vulnerable in society (Rowlingston, 2001: 107).

Poverty is a highly contested concept. So far, there has been no universally accepted definition of poverty, its measurement, extent, causes, and solutions because poverty remains a complex political, economic, moral, and social issue (Donnison, 2001; George, 2004). For George, poverty is multifaceted and consists of unacceptably low levels of nutrition, income, health, and education. As George argues, comparisons of the extent of poverty between industrialised countries and developing countries are more meaningful if poverty is understood to mean a 'continuum of deprivation with under-nutrition at the harsh end and lack of social participation on the other, more generous end' (2004: 62-63). This definition has been challenged particularly in the context of Britain where in the late 1980's the incomes of the top 10 percent richest people in the country increased rapidly (Blakemore \& Griggs, 2007). Dean (2002) outlines two definitions: absolute poverty and relative poverty. Absolute poverty applies only to people with 'insufficient resources for physical survival', while relative poverty - as Townsend (1979) and Donnison (1982) observed - applies to people with 'insufficient resources for normal social participation' (Dean, 2002: 21). In other words, poverty in the relative sense means that if one's incomes are below the national average one is therefore considered poor. Thus, incomes of poorer groups are defined in relation to the average incomes in society (Blakemore \& Griggs, 2007: 98). According to the World Bank, people whose incomes fall below US\$1 a day are defined as poor because this amount is 'grossly inadequate for industrialized countries' (World Bank, 2000: 23). However, it should be noted that defining poverty on the basis of income only is grossly inaccurate because the income indicator does not take into account other factors that make poverty multidimensional (Kankwanda et al., 2000). Kankwanda et al. succinctly describe the factors that influence poverty: "poverty is recognised as a multidimensional phenomenon, influenced by a wide range of factors such as poor people's lack of access to income-earning and productive activities and to essential social services' (2000: 3 ).

To ensure a more comprehensive description of poverty in relation to human development, economists Mahbub ul Haq and Amartya Sen developed non-income indicators of poverty from which UNDP developed the Human Development Index (HDI) in 1993 and later the Human Poverty Index (HPI) in 1997 which encompass these social 
dimensions of poverty. The HDI is 'a composite index measuring average achievement in three basic dimensions of human development: a long and healthy life, knowledge, and a decent standard of living' (UNDP, 2014a: 167). The 'composite statistic of life expectancy, education, and income indices are used to rank countries into four tiers of human development': very high, high, medium, and low human development (UNDP, 2014b). The objective of development therefore is 'to create an enabling environment for people to enjoy long, healthy and creative lives' (UNDP, 2014b). But, as the 2014 Human Development Report (HDI trends for 1980-2013) shows that the majority of sub-Saharan African countries have consistently recorded the lowest human development, crammed up in the first quartile with the exception of just a few countries which managed to get into the fourth quartile (UNDP, 2014a: 164-167). A further Inequality-adjusted Human Development Index (IHDI) was introduced and added to the HDRs in 2010 by the UN (UNDP, 2010). The IHDI is considered as the 'actual level of human development (accounting for inequality)', while the HDI is understood as an index of 'potential' human development achievable if there were no inequalities in society (UNDP, 2014b).

It can be seen from the above analysis that poverty encompasses people who are poor at all times as well as those who move in and out of poverty and constitute the majority (Baulch \& Hoddinott, 2000). These are the 'transient poor who may slip in and out of poverty over the course of their lifetime, while the chronically poor remain in a constant state of deprivation throughout their entire lives and consistently lack basic needs of food, water, housing, healthcare and education, which are essential to support an adequate standard of living (Harrington, 2011: 4).

\section{Social Protection and Poverty Reduction}

The failure of the neo-liberal policies of the World Bank and IMF to reduce poverty in developing countries in the early 1980 s to early 1990 s compelled most of these countries to adopt alternative poverty eradication strategies such as social protection (Ncube et al., 1987). Apart from providing a policy framework for addressing poverty and vulnerability, social protection embodies and extends alternative approaches to economic and social development such as social cash transfers. More recently, there has been an increasing interest in social protection as a tool for poverty reduction. This change can be seen from the increasing number of countries espousing social protection strategies and growing interest in social protection among researchers (Barriendos \& Hulme, 2013: 3).

Social protection can be defined as social policy intervention encompassing a broad range of public actions that provide direct support to poor people to help them deal with risk, vulnerability, social exclusion, hunger, and poverty (Conway et al., 2000). Social policy is a key aspect of social protection and it essentially articulates the provision of social security, benefits, education, health, and social care to improve the rights and welfare of individuals in society and helps to understand how policies develop and operate in the social world (Beckler et al., 2012: 4). The principles of social policy are the ideas that underlie social protection and embedded in equality, need, freedom, and rights (Griggs, 2007: 37). The central principle underpinning social protection is that the underlying causes of poverty are "to be found in the constraints faced by the poor in taking advantage of economic opportunity arising from their vulnerability to the impact of economic, social and natural hazards' and that social protection helps to elucidate on the dynamic nature of poverty (2013: 4-5).

There are three major elements that constitute social protection: social insurance, labour market regulation, and social assistance (ILO, 2001). Social insurance consists of contributory schemes managed by governments, which provide financial support to recipients such as the unemployed, the injured, and the aged in times of hardship using contributions from employers and employees as well as the government revenue. Labour market regulation provides a legal and policy framework that defines and protects citizen's rights and ensures minimum civic standards to safeguard the interests of individuals (such as labour laws, health and safety standards). Social assistance refers to non-contributory, regular and predictable grants, in cash or in kind, which are provided to vulnerable households or individuals in order to ensure a minimum level of well-being (HMSCTS, 2013; Chapman, 2006). Social cash transfers are an example of social assistance.

Social protection performs three critical public functions: protect basic levels of consumption among those in poverty or in danger of falling into poverty; facilitate investment in human and other productive assets that alone can provide escape routes from persistent and intergenerational poverty; and strengthen the agency of those in poverty so they can overcome their predicament as a result of chronic shocks and vulnerability (HMSCTS, 2013: 4).

The provision of essential public services, welfare, education, health care, nutrition and other opportunities to reduce poverty and promote social and economic rights, is one of the most distinctive features of the modern welfare state (Dean 2002: 4). The welfare state is 'a system in which the government assumes the main responsibility of providing the social and economic security of the state's population through pension, social security benefits, free health care, education, and so forth (McLean \& McMillan, 1996: 570). This welfare regime rests on the principle that 'some people's access to health, education, and personal welfare depends on the intervention of the state in other people's freedom to arrange these as they choose' because 
people do well or badly depending on their social circumstances (Oakley \& Williams, 1994: 6). Welfare rights are not an entitlement to a hand-out' but claims to social arrangement, embodied by norms, institutions, laws, policies and an enabling economic environment that can best secure the enjoyment of social and economic rights (UNDP, 2000: 73).

Social policy, like any other public policy, is concerned with social transformation. There are different approaches to social protection which can be traced back to three many perspectives on social transformation in which social protection is anchored. These are the rights-based, needs-based, and risks-based approaches to development. The rights-based approach is a human development framework based on human rights norms and standards intended to promote human rights (Nyamu-Musembi \& Cornwall, 2004: 13). The rights-based approach is a 'systematic way of addressing poverty and development by strengthening human rights' (Decker et al., 2006: 25). The approach provides a normative framework for developing the human capacity to claim against the state social services and opportunities as entitlements (Amparo, 2005: 7; Piron and Watkins, 2004: 16). This approach is based on the principle that human development discussion must have a broader view of human rights. In other words, human rights are not limited to civil and political rights only, but encompass social and economic rights. Conversely, poverty does not only denote lack of income but also encompasses deprivations in terms of healthcare, education, participation and security. Hence, from a human development perspective, human rights and poverty are multidimensional (Kankwanda et al., 2000). The rights-based approach is also based on the argument that poverty is a denial of human rights because it violates freedom and human dignity and subsequently leads to social exclusion and inequalities. A significant aspect of the rights-based approach is that it is not only an analytical tool, but also a poverty eradication strategy with significant implications on poverty reduction (Jahan, 2004). In conventional poverty reduction approaches there are no obvious duty-bearers who should be made accountable if the needs of rights-holders or claimants are not met or promises are broken. But in a rights-based approach people can claim against duty-bearers their right to development because accountability and transparency are the hallmarks of this approach (Jahan, 2004: 1).

In recent years, there has been an increasing interest among development agencies to adopt a rights-based approach to poverty reduction (Nyamu-Musembi \& Cornwall, 2004). Among UN agencies, UNICEF was the first to apply the rights-based approach in its programming (Nyamu-Musembi \& Cornwall, 2004). This can be traced back to its earlier efforts throughout the 1980s and 1990s to make the development process more people-centered using the 'Adjustment with a Human Face' when it criticised the structural adjustment policies of the World Bank and IMF (2004: 21). It is however important to note that the rights-based approach has no significance on poverty reduction and development if it does not lead to 'a positive transformation of power relations among the various development actors' (Nyamu-Musembi \& Cornwall, 2004). In other words, a rights-based approach must 'enable those whose lives are affected the most to articulate their priorities and claim genuine accountability from development agencies' and make duty-bearers 'become critically self-aware and address inherent power inequalities in their interaction with those people.'

The needs-based approach is a socialist theory of justice based on the Marxist idea of wealth or material benefits, as proclaimed by Marx: 'from each according to his ability, to each according to his needs!' (Heywood, 1994:236). The theory focuses on the satisfaction of basic needs. Needs are requirements such as food, drink, shelter, and love, which must be satisfied to avoid causing harm to an agent (McLean \& McMillan, 2003). Needs differ from wants in that they are universal, whereas, wants reflect individual circumstance and taste. More importantly, deprivation of needs constitutes harm to an individual and their satisfaction is fundamental to a person's wellbeing (2003: 367). In addition, other scholars regard physical health and autonomy as essential preconditions for participation in social life (Heywood, 1994). In Maslow's 'hierarchy of needs' basic needs are classified as physiological considerations such as hunger and sleep, followed by need for safety, belonging and love, self-esteem, and finally self-actualisation. Scholars such as Doyal and Ian Gough regard physical health and autonomy as essential preconditions for participation in social life (Heywood, 1994). Others argue that the satisfaction of basic needs promotes human dignity.

The problem with the needs-based approach is that it is based on a futuristic 'society of such abundance that questions about the distribution of wealth become almost irrelevant' (Heywood, 1994: 236). As Heywood argues, the merits of the needs-based theory are that it 'addresses the most fundamental requirements of the human condition,' that is, basic needs because of its acceptance of the universal moral imperative that all human beings are entitled to the satisfaction of their basic needs, without which no meaningful human existence would be possible (1994: 237). It is argued that if needs are the same the world over, material resources should be distributed to satisfy each and every person, which means that every human being should have access to food, safe drinking water, housing, adequate health care and some form of personal security. However, the reality is that needs are not the same everywhere. Both conservatives and liberals argue that as a concept, the word 'needs' is too abstract and detached from the actual people and that the allocation of resources should be dependent on individual preferences; 
the existence of needs is conditioned by the historical, social, and cultural context in which they arise and are met (1994: 238).

The risks-based approach is defined in the context of the 'lifting of constraints to human and economic development posed by social risks' (Barriendos \& Hulme, 2013: 4-5). The World Bank defines social protection as a 'social risk management' framework with the addition of 'macroeconomic stability and financial market development to typical social protection programmes' (Barriendos \& Hulme, 2013). Social risk management refers to public interventions intended 'to assist individuals, households and communities in better managing income risks' (Holzmann \& Jorgensen, 1999; 2000). The emphasis on risk is premised on the assumption that vulnerability significantly constrains economic and human development and that development presupposes reduction of the likelihood of hazards. The World Bank is 'often accused of having a narrow framework focused on 'safety nets' (Barriendos \& Hulme, 2013: 5). Other multilateral institutions propose different policy frameworks based on their own definitions of social protection. ILO, for example, regards social protection as human rights since it is an entitlement to benefits society provides to vulnerable individuals and groups to protect them against low or declining standard of living caused by basic risks and needs (ILO, 2013: 6). For UNICEF, social protection is a key strategy for ensuring the survival and development of 'children exposed to multiple deprivations as a result of chronic or short term shocks' (UNICEF, 2014b). And UNDP defines it as 'a set of public and private policies and programmes undertaken by societies in response to various contingencies to offset the absence or substantial reduction of income from work, to provide assistance to families with children as well as provide people with basic health care and housing' (UNDP, 2000: 4). The distinctly different positions these institutions take on social protection both militates the actions they take within themselves on rights-based approaches to poverty eradication and those they are in a position to promote in collaboration with development agencies (Nyamu-Musembi \& Cornwall, 2004: 15).

Although there are varying definitions of social protection, it can be concluded that these different approaches to social protection are fundamentally rooted in the rights-based approach to development. Understanding the conceptual underpinnings of the different policy frameworks development institutions propose for poverty reduction helps to determine what practical actions that must be emphasised in any poverty reduction framework (Barriendos \& Hulme, 2013: 5).

\section{Research Methodology}

This study applied a qualitative case study approach.
Qualitative research is a social science research method that emphasizes the 'qualities of entities, processes, and meanings that are not experimentally examined or measured' (Denzin \& Lincoln, 2000: 2-4). Mason (1996) observes that qualitative research has a subjective approach to studying social phenomena and does not stand for a unified set of philosophies or techniques, but represents a wide range of techniques and methodologies, rooted in an interpretivist philosophical orientation. Qualitative research is concerned with 'how the social world is interpreted, understood, experienced or produced' (1996: 4). In qualitative research, the researcher's closeness with the subject ensures an insider's view of the social reality under inquiry, which could reveal complex realities such as causes and effects which, normally, are missed out in positivist inquiries (Burns, 2000: 13).

A case study is one of the five approaches used in qualitative research (Creswell, 2007). Whittaker (2012) defines a case study as a detailed investigation of a single or small numbers of cases (such as an organization, individual or event) that gives focus to the research (2012: 128). Such a detailed investigation helps to identify phenomena, themes, concepts, or principles from which theory can be developed or practice improved. One of the weaknesses of a case study is that the case may turn out to be too different and its findings may sometimes be irrelevant to other contexts (Hazell, 2010). However, this potential problem can be addressed by ensuring that the study does not focus 'too narrowly on the individual-ness of the case, and remaining aware of the wider context within which it nestles' (2010: 33).

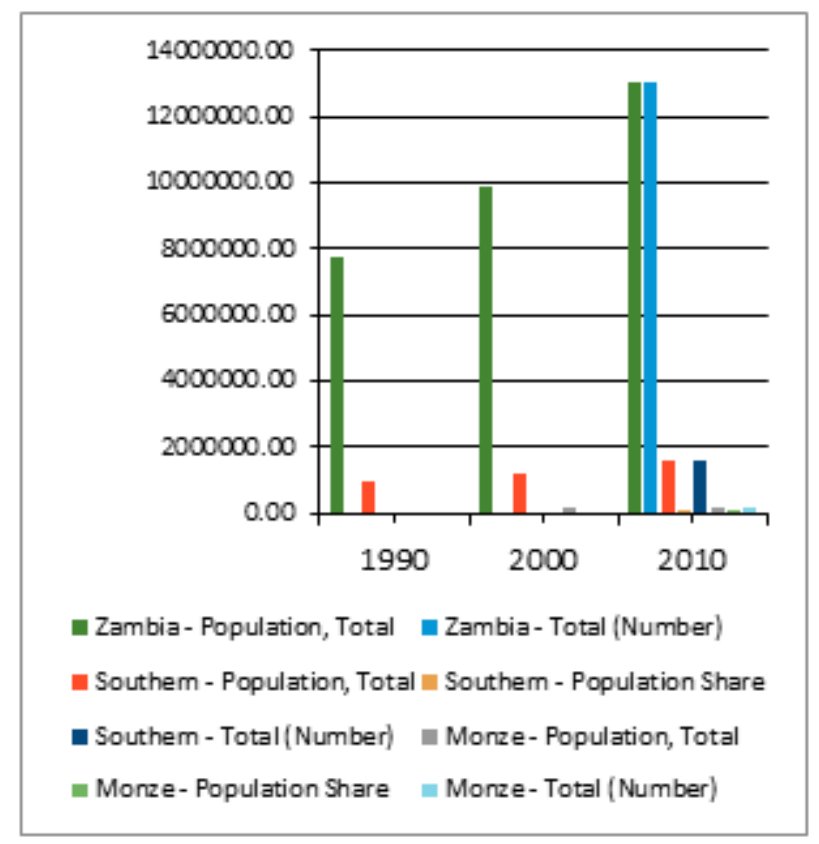

Source: Zambia Population and Housing Census Data, 1990-2010

Figure 1. Zambia Population Total with Monze and Southern Province 


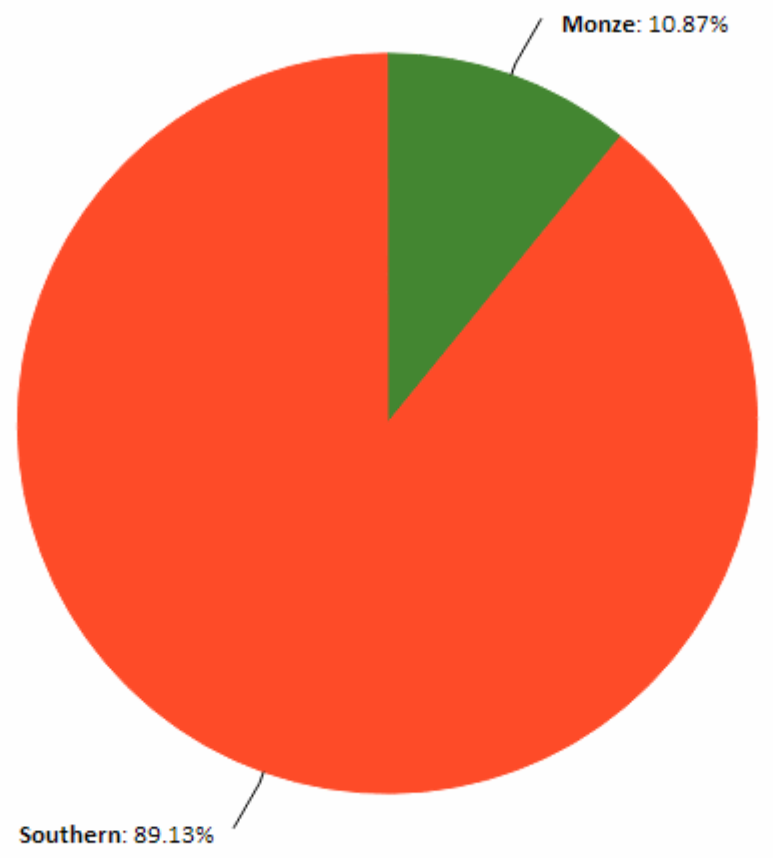

2000

Source: Zambia Population and Housing Census Data, 1990-2010

Figure 2. Monze Population Share of Southern Province

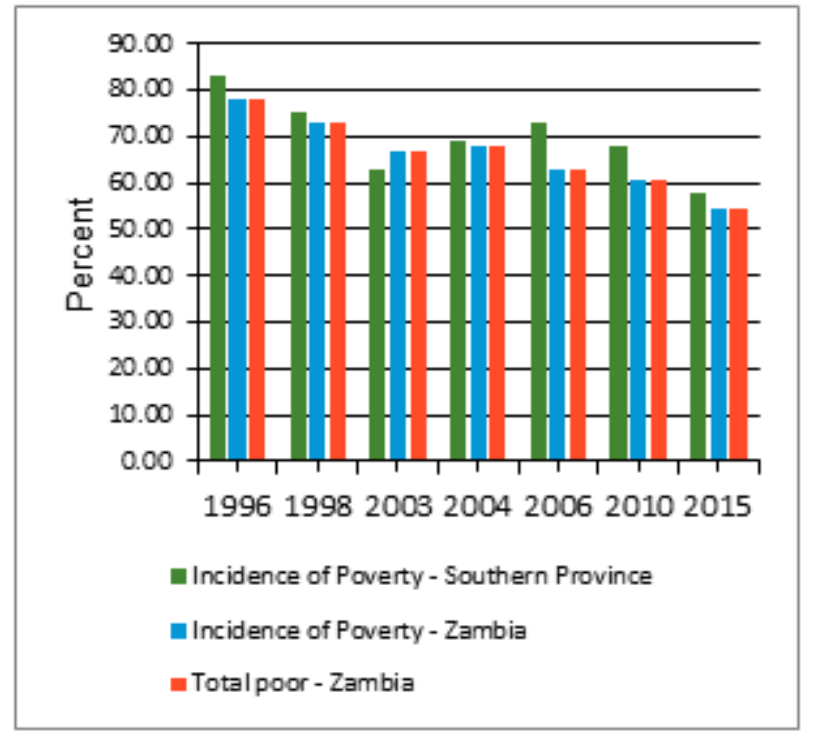

Source: Zambia Population and Housing Census Data, 1990-2010

Figure 3. Zambia Poverty Incidences Monze and Southern Province

\subsection{Study Area}

For practical and resource-based reasons and to ensure focus, this research study focused on Monze, a rural district in Southern Province of Zambia situated about $180 \mathrm{~km}$ south-west of Lusaka, the capital city. According to the 2010 population census data, Southern Province accounted for 1.6 million of the national population with Monze having a provincial population share of 10.8 percent (CSO, 2010: 6) as shown Figure 1, 2, and 3. Seventy-eight percent of the people in Southern Province live in rural areas and 63.8 percent are classified as poor, with consumption per adult falling below the poverty line (World Bank, 2014). The district was chosen as a case study because it has the potential to produce rich data for a proper assessment of the impact of social cash transfers on children's rights. Moreover, there are adequate structures for the collection of primary data and recipients and non-recipients of social cash transfers were readily available to participate in the research.

\subsection{Sampling Procedure}

Research participants were selected using purposive sampling. Sampling is commonly used in qualitative case studies to 'select the case or cases for study from the basic unit of study where it is impossible to cover all instances of the unit' (Becker et al., 2012: 410). A sample can be people or other data sources 'chosen from a possible data sources, known as the population' (Whittaker, 2012: 3). It was way beyond the capacity of this study to cover all the units of 
the study area, hence the employment of sampling. Purposive sampling is a procedure whereby the researcher selects research participants deemed likely to yield critical information based on factors such as participant's knowledge, experience, or role played in relation to the subject under inquiry (Whittaker, 2012). 'Interviews are most successful when participants have significant experience in the research topic' (2012: 39). Purposive sampling procedure ensures that the number of research participants is 'determined on the basis of theoretical saturation and is most successful when data review and analysis are done in conjunction with data collection' (Mack et al., 2005: 6). This was the strategy employed in this study. There were two groups of interviewees: recipients and non-recipients of social cash transfers. Although children in recipient households were also beneficiaries of social cash transfers, the interviews were restricted to adult participants only, purposively selected on the basis of their experience of the social cash transfer programme as recipients. Children were excluded for ethical reasons. The other group of interviewees, non-recipients, includes government officials and programme managers from intergovernmental and non-governmental organizations directly supporting the social cash transfer programme, civil society, education and health sectors, community leaders, and other independent researchers. This group was chosen not only for their knowledge of the social cash transfer programme but also for their expertise in the field as well as their special role in the implementation and evaluation of the cash transfer programme. As such, unlike the first category of research participants, the latter's geographical location was not restricted to Monze.

\subsection{Secondary Sources}

While the study was anchored in primary research, it also consulted secondary sources. Sources for such data included research reports, journal articles, books, and other relevant publications by other researchers in the field. Secondary data were useful in that they provided a background of the subject area and research context, given the fact that they are readily available and are produced by a team of expert researchers usually with extensive resources at their disposal (Walliman, 2011: 177). The other reason why secondary data were used is that they save time and provide a much larger and reliable database (Bryman, 2012: 13). The method of gathering secondary data was also quicker and the data were easily accessible (Bryman, 2008; Sarantakos, 2005). Secondary data are also convenient in that the research can be done at any time without any time restriction. In this way, the research is less time-consuming and as such left the researcher with more time for analysis. Moreover, because they do not deal directly with people, meant that the possibility of encountering rejection, nonresponse or bias was diminished.

\subsection{Data Analysis}

'Data analysis refers to the process of reducing large amounts of collected data to make sense of them' (Kawulich, 2004: 97). In qualitative research, this requires 'preparing and organising the data' for analysis and final representation of the data into figures, tables, or a discussion (Creswell, 2007: 148). The analytical approach the study used to analyse research data was narrative analysis. Narrative analysis was used to unpack the underlying themes that run through the interview transcripts. The interviews were recorded using semi-structured interview questions and questionnaires and transcribed manually. Thereafter, using an analytical framework that was developed, data were then summarised and classified into data sets under thematic headings using tables. Analysis and reporting involved detailed examination of the emerging themes and under each of the research questions that underpin the study, with findings presented as a concise and coherent narrative reflecting the argument of how the data respond to the research questions, while remaining grounded in the language of the study's participants. From this data analysis, the researcher was then able to draw general inferences or 'naturalistic generalisations' which other research users can learn from the case either for themselves or to apply to a population of other cases on a wider perspective or context (2007: 148-164).

\subsection{Rationale}

The choice of this methodology was mainly guided by research questions and objectives (outlined in Section 1). This research approach has been adopted because it provided the most ideal theoretical basis that could guarantee an in-depth understanding of the impact of social cash transfers on children's rights (Creswell, 2007: 74). Monze was chosen as a case study on the premise that as one of the first districts to be piloted in so far as the social cash transfer programme, the area potentially offered rich data. Further, the strategy of combining semi-structured interviews and documentary analysis was intended to ensure a coherent and thorough assessment of how social cash transfers have impacted on children's rights and welfare. The approach of interviewing recipients and non-recipients of social cash transfers using two varied sets of questions was premised on two reasons. The first is that interviewing recipients separately helps in getting original, non-technical perspectives of how cash transfers have impacted on their livelihoods in terms of poverty reduction. This technique was also intended to assess, from their perspectives, how the cash transfers have impacted on the rights of children from recipient households. Having this information was important in that it helped dispel any 
anecdotal evidence that the research came across in the process of collecting data. Secondly, interviewing non-recipients was intended to provide technical insights into the social cash transfer programme. Getting the opinion of policymakers, programme managers, implementers, researchers, and other analysts on cash transfers helped to clarify many issues regarding the sustainability and effectiveness of the social cash transfer programme. It also provided a framework for a comprehensive assessment of social cash transfers because this group of participants was more competent to comment on the technical aspects and policy implications of social cash transfers.

\subsection{Ethical Considerations}

Given the type of research methods applied in this study and the types of research participants, there are certain ethical issues that could arise during the research process, particularly during interviews, data collection, analysis, and writing up. University approval was sought and granted prior to undertaking the study. The interviews focused on two types of research participants: recipients and non- recipients of social cash transfers. All research participants - from the targeted households - were adults from vulnerable, poor households with varying degrees of vulnerability and poverty levels, educational background, occupation, and so on and the majorities were unemployed, poor and vulnerable. However, no single ethical issue arose during and after the research process. Becker et al. (2012) states that failure to discuss the management of certain aspects of the research and how they were managed casts doubts as to whether the research was conducted to a high standard of ethical conduct (2012: 57). To ensure the required rigorous methodological, ethical, and procedural standards, four ethical issues were considered and adequately addressed in this study. These are: respect for research participants; protection of research participants; public and professional responsibility of the researcher; and, honesty in communication.

Securing the prior consent of research participants is essential for any kind of research involving participants. Before research participants were interviewed in this study, the researcher sought their consent whether and how to engage in the interview. Written information was read out or provided to candidate research participants about the researcher, the nature of the research, and purposes for which the research is being conducted before engaging them. This was to allow potential participants make an informed consent if they chose to proceed with the interview. The participants were also informed that they could withdraw from the interview at any time if they chose to. For instance, one participant opted out at the start of the interview after giving consent. The researcher had selected him for his significant role as head teacher of a school located in a village where the social cash transfer programme was being implemented.

Particular attention was also given to the ability of the research participants to understand the information and give meaningful consent. The questions were simplified further for participants with low levels of education. During the interviews the research participants were treated with courtesy and their reluctance or refusal in interviews was respected and their contribution to the overall research objective has been fully acknowledged in this paper. Interviewing research participants can be potentially upsetting and a nuisance (Whittaker, 2010). To avoid upsetting research participants and ensure their protection from physical or psychological harm, the researcher offered anonymity in written accounts by concealing the identities of research identities and maintaining confidentiality. The researcher also had in in mind that some research participants could specifically wish to be named in this research. No occasion for such a scenario arose.

\subsection{Research Limitations}

Despite several logistical and methodological challenges the study encountered, the research methods the study adopted were considered as the most ideal approach to effectively assess the impact of the social cash transfer programme on poverty reduction and children's rights in Zambia. The potential challenges associated with this method were carefully considered and remedial actions taken where necessary. To start with, it is often argued, for example, that the subjective nature of qualitative data and their restriction to single contexts make their validity and reliability too inadequate to be generalized to a wider context (Burns, 2000: 12). In particular, 'the use of case studies in research studies is often perceived as a limitation on the premise that the findings of a case study are not sufficient to be applied to a wider context (Chama, 2010: 30). In contrast, it can be argued that interviews provide indispensable data, data which can validly be generalised on a broader area (Alvesson \& Skoldberg, 2000). It follows that, because it was rooted in primary research - through semi-structured interviews and questionnaires - the findings of this study are empirically grounded and are generalizable because the data obtained from the interviews provide the foundation for its reliability and validity (Alvesson \& Skoldberg, 2000: 1; Miles \& Huberman, 1994).

Further, it is stated that anonymity in qualitative research is usually diminished because of the intimacy that develops between the researcher and the subject (Parlett, 1975), which has implications for the 'right to information, right to privacy, right to data protection, and confidentiality' (UN, 2012: 49-51). In addressing this issue, the strategy adopted was that before each interview was conducted, the researcher took time to explain the purpose and nature of the interviews, it objectives, and the rights of participants 
during the process, including the right to opt out of the interview at any time or decline to answer certain questions they were unfordable about.

The research was conducted to an acceptable methodological standard of rigorous data collection and analysis and in a manner that conforms to legal and institutional ethical standards. Bryman holds that with qualitative data - unlike quantitative data - there are no established rules for analysing them, thus making it difficult to analyse interview scripts, field notes and documents (2008: 538). While this is correct (Whittaker, 2012), the potential problem was resolved by data collection and data analysis simultaneously and the process continued throughout the research process.

It is also argued that there is always a possibility that not all documents can be accessed, while some documents might have incomplete and outdated data and unreliable sources which makes documentary analysis very difficult (Sarantakos, 2005). To ensure authenticity and reliability of secondary data, an assessment of secondary data sources was made to determine the credibility of the organisations supplying the data before such data were used. The documents so far used in this research (both hardcopies and online materials) were scrutinised. They included published books and articles from credible sources (academic journals, and official government publications, as well as publications of reputable organisations such as the UN, World Bank, UNICEF, DFID, USAID, ILO, UNDP, GIZ, CIDA, and JCTR. The records held by smaller organisations, which tend to be less reliable, were crosschecked with the persons or institutions responsible for generating the data.

Furthermore, it is argued that secondary data are prone to a lot of mismatches in the terminology, style of collection and analysis, which make aggregation of data very difficult and open to challenge (Walliman, 2011). While it was notable that a number of documents consulted had different terminologies and definitions of key concepts, the research focused more on materials that are academically grounded in terms of methodology and means of gathering data.

Lastly, while the study endeavoured to add a critical perspective to literature on social protection and, in particular, social cash transfers (in terms of key issues and challenges affecting their implementation and possible solutions needed to resolve them to effectively reduce poverty in developing countries), it had a defined and therefore limited scope. As such, it could not inquire into other broader areas. However, its findings can be used as a trajectory that points to possible areas for future research. Such areas may include an inquiry into whether the emerging welfare regimes among African states suggests a shift to accept social and economic rights as concrete rights to be fully entrenched. In spite of the notable research limitations the research encountered, the study arguably contributes to the elucidation of social protection as a tool for poverty reduction. This is significant given the growing trend by many countries in sub-Saharan Africa to use social cash transfers to tackle poverty.

\section{Social Cash Transfers and Children's Rights in Zambia}

Zambia started receiving support from the World Bank in 1955 (before attaining political independence) (World Bank, 2014). Since then, the country has been struggling to reduce poverty (CSO, 2010; World Bank, 2012; World Bank, 2004), while the World Bank, IMF, and other multilateral lending institutions have continued to be 'financial gate-keepers of Zambia's poverty reduction and development programmes' (Seshamani, 2005). From 1980 into early 1990s, the government implemented various poverty reduction strategies including Structural Adjustment Policies (SAPs) aimed at reducing poverty and improving the living conditions of the people. As a result, by mid-1990s the full negative effects of these policies were deeply felt by the people, especially women and children, characterized by widespread reductions in social expenditure, food subsidies, and the provision of social services. In its effort to prevent further economic recession, the government launched the Economic Recovery Programme aimed at stopping economic decline so as to improve living standards in the country (CSO, 2009; World Bank, 2004; Saasa, 1996; Ncube et al., 1987; Magketha, 1986). The economy relatively improved during the implementation of the Poverty Reduction Strategy Paper (PRSP) and the Transitional National Development Plan from 2002 to 2005. However, in spite of Zambia's decade of economic growth, from 2000 to 2010, the country recorded very little progress in 2012 in reducing poverty (World Bank, 2012). Inequalities in the country remain among the highest in the world with increasing disparities between rural and urban areas compounded by a slow pace of poverty reduction (UNDP, 2013b: 10-18). To tackle poverty and reduce vulnerabilities, the Zambian government began implementing social cash transfers in 2004 as one of its poverty reduction strategies.

Zambia implements four types of social cash transfers that target 'ultra-poor' households with labour constraints. These are the inclusive model, social pension scheme, multiple categorical targeting scheme, and child grant scheme (HMSCTS 2013). The inclusive model targets 10 percent of the total households considered destitute and incapacitated. Destitution refers to a situation where a household struggles to survive and resorts to detrimental copying mechanisms to survive the shocks, has less than three meals a day, have inadequate housing and clothing, and limited access to education and health services. A household is classified as incapacitated if it has no fit for work members or if it has a high dependency ratio (ratio of unfit members divided the number of fit members in a household) (HMSCTS, 2013: 6). The social pension scheme universally targets persons above the age of 60 . This type of scheme does not target households but only 
targets eligible individuals. The criteria to qualify for the scheme are mainly that one must be 60 years or older, hold a Zambian national identity document, and be domiciled in the designated area for not less than one year continuously (HMSCTS, 2013). The multiple categorical targeting model targets individuals 'by universal categorical targeting.' The scheme targets households headed by females keeping orphans, others headed by elderly people aged 60 and above keeping orphans, and those with at least one member with a disability (HMSCTS, 2013: 6). The child grant scheme is a special categorical targeting scheme for households with children under the age of five. To qualify, the child must be under 5 years old, while the head of the household must be a Zambian or a resident. In addition, the applicant must be the mother to the child or a primary care giver directly responsible for the mother, and that at the time of application the child must be three years or less and lived continuously for six months. However, households with older children with disabilities may be considered as special cases under the scheme (HMSCTS, 2013:6-7).

The successful implementation of social cash transfer programmes depends on the institutional arrangements within which they are designed and implemented (HMSCTS, 2013; Samson et al., 2010). There are three elements required for effective policy coordination: sincere and durable commitment to social protection; political influence to secure scarce resources for social cash transfers and the power to negotiate trade-offs and defend the framework's priority; and, institutional or administrative capacity to design and successfully manage the programme. The presence of these three elements provides an overall policy coordination process that ensures coherence in policy coordination and strong monitoring and evaluation function. Further, the coordination process also plays an important role in harmonising development partner support, and effective interventions usually require the involvement of several other government departments (Samson et al., 2010: 51-52).

Zambia is state party to various international and regional human rights instruments, including the Universal Declaration of Human Rights, the Convention on the Rights of the Child, and the African Charter on the Rights and Welfare of the Child, which underpin children's rights at global level. For example, Article 27 of the Convention recognises the 'right of every child to a standard of living adequate for the child's physical, mental, spiritual, moral and social development.' The right to an adequate standard of living depends on several other social and economic rights including the right to right to work, the right to education, the right to social security (Andrews \& Kaufman, 1999). In addition, Article 26 outlines a range of other children's social and economic rights: 'States Parties shall recognize for every child the right to benefit from social security, including social insurance, and shall take the necessary measures to achieve the full realization of this right in accordance with their national law.' These instruments provide an international legal framework for the protection of children's rights in Zambia, while the constitution and several other laws provide a legal framework at domestic level. In addition to this legal framework, children's rights are social and economic rights are also articulated in the National Plan Vision 2030 (MOF, 2006). The plan is an aspiration and determination of the Zambian people to take decisive steps towards laying a solid foundation for building a sustainable and prosperous future aimed at transforming Zambia into a prosperous middle-income industrial nation by 2030 (MOF, 2006).

Despite these protective frameworks, the implementation of social and economic rights for children in Zambia has been hampered, as most substantive provisions of these instruments have not been fully internalized in the country's laws and policies. Lack of political will and commitment to international human rights obligations are often cited as some of the key factors that have constrained the full implementation of children's rights in Zambia (Chanda, 2001). It is also noted that the Zambia's dual legal system presents further constraints in so far as implementing human rights norms and standards articulated in international instruments Zambia is party to. The Zambian constitution requires that an Act of Parliament must be passed to transform all international treaties, conventions and agreements into domestic law if they are intended to have domestic application. In the absence of such integration, as Anyangwe noted, a treaty such as the Convention on the Rights of the Child, though binding at international level, has no internal applicability (1997: 19). Other scholars have also argued that the absence of domestic rules of interpretation of domestic law in line with treaty obligations makes judicial enforcement virtually impossible (Heyns \& Viljoen, 2001: 490).

\section{Impact of Social Cash Transfers: Findings and Discussion}

Besides secondary sources, the findings of this study are based on responses obtained from selected individuals from 100 beneficiary households in four villages in Monze district (namely Hanamaila, Nteme, Luyaba, and Choongo) and six other non-beneficiary informants (three in Lusaka and three in Monze) using interviews and questionnaires. Although the six informants were not beneficiaries of the social cash transfer programme, their feedback was critical given the fact they were directly involved in the design, implementation, and monitoring of the social cash transfer programme in Zambia. Hence, their perspective on social cash transfers helped further clarify a number of issues from a policy and programme point of view. All these research participants were engaged to gain a deeper insight into the impact of the social cash transfer programme on 
poverty reduction and children's rights and their responses were compressed into a single data set, which was subsequently analysed using thematic analysis, to identify, analyse and report patterns or themes abstracted from the data. Similarities and dissimilarities between themes were carefully identified and studied to come up with a meaningful and coherent narrative. The study findings were classified into thematic areas, each pattern following the scope of the research and questions posed. These are: participants' understanding of social cash transfers; impact of social cash transfers on livelihoods, children's education, health and nutrition; sustainability of social cash transfers; and, challenges affecting the social cash transfer programme.

\subsection{Understanding of Social Cash Transfers}

On the question of how participants understood social cash transfers, participants understood that social cash transfers are 'regular and predicable' cash transfer payments to the poor and vulnerable and incapacitated households intended to reduce extreme poverty and destitution. Participants emphasised this point as fundamental to the essence of social cash transfers. One of the participants explained that in dealing with households that are constantly vulnerable to shocks and risks, it was imperative that the cash transfer payments are 'regular and predictable.'

Social cash transfers 'differ from in-kind interventions such as the provision of food or food stamps, in that with cash transfers the recipient has the power and choice on how to use the cash given' (Ressler, 2008). The other dimension that participants stressed was that social cash transfers are an income that incapacitated households rely on for their survival. The future expectation of a predictable and regular income the social cash transfer programme creates among recipients motivates them to take measures aimed at improving livelihoods through productive ventures such as investing in agriculture, livestock and small businesses. Although the percentage of recipients who invested in livestock, labour, construction, small businesses and agricultural production was, expectedly, small the significance of this finding is it affirms the assertion among development economists that 'the importance an individual places on immediate versus delayed consumption plays a key role in the economic models of savings, growth and economic development' (Seidenfeld \& Handa, 2011: 28-29). It is evident, from this analysis, that participants who invested their cash payments into productive ventures demonstrate an inability to delay immediate consumption on the basis that the regularity and predictability of social cash transfers change their expectations about the quality of their lives and motivate them to invest in the future and engage less in risk behaviour.

"A predictable source of income can alter individual discount rates, making recipients less myopic and more forward looking, and more willing to delay current consumption for future investment such as schooling of children, or health and economic activities which provide benefits in the future rather than the present (Seidenfeld \& Handa, 2011: 30)."

It can be seen from this analysis that, investing in livelihoods is the kind of progress that leads to improvements in the standard of living envisaged in any poverty eradication strategy. Social protection-including social cash transfers are a component - is not only intended to help protect the basic levels of consumption among those in poverty or in danger of falling into poverty, but also to facilitate investment in human and other productive assets that act as 'escape routes' from persistent and intergenerational poverty (Barriendos \& Hulme, 2013: 4). Poverty reduction and prevention of intergenerational transfer of poverty is the main objective of social cash transfers (MCDMCH, 2013). Such progress is what development entails.

However, although they are 'regular and predictable' the research found that social cash transfers have not always been paid regularly. One of the key formants revealed that the cash transfer payments are sometimes delayed, for various reasons, including logistical challenges. Acting on the expectation that the cash transfers would be paid based on the understanding that the payments are 'regular and predicable', participants have had to walk four to five days to the pay point in expectation of a payment, but only to be informed by PPMs (Pay Point Managers) that the cash transfer payments were not ready. And PPMs have, on humanitarian grounds, had to accommodate the recipients in such circumstances until the payments were ready to be paid out. This finding is consistent with what Seidenfeld \& Handa (2011) found in 2011 assessment of the programme, which hinges on the government's capacity to effectively implement the social cash transfer programme. Moreover, participants, consistently mentioned the issue of lack of capacity, especially at the district level to effectively implement social cash transfers and ensure timely payments.

It should also be noted that delays in paying beneficiaries undermines the very essence: reduction of vulnerability, risk, hunger and poverty among its targeted beneficiaries and risks causing more chronic poverty in situations where grants are dependent on such incomes. In their study, Sanfilippo et al. (2012) noted that when beneficiaries become dependent on these grants and do not receive them at the expected time, they resort to negative coping mechanisms that are detrimental such as taking children out of school, cutting down on healthcare, substandard nutrition, and engaging in less productive activities. A few participants revealed that when they do not receive cash at the expected time, they resort to eating wild fruits. This clearly shows that the social cash transfers after all are not always regular and predictable and will 
continue to be unpredictable unless some logical and administrative challenges are addressed.

\subsection{Impact on Livelihoods, Children's Education, Health and Nutrition}

As regards the question of the impact of social cash transfers on livelihoods, several participants observed that they were able to invest the social grant on productive ventures such as livestock. Others used the money to refurbish or build new houses. Participants generally felt their standard of living had improved as a result of the social cash transfer payments and this gave them a sense of well-being. This finding reiterates the assertion that using cash transfers as a form of social protection in situations of acute poverty, hunger and vulnerability, increases a sense of well-being and dignity among beneficiaries in ultra-poor households (Ressler, 2008: 1-4).

So far as impact on education, a significant number of participants ( 80 percent) reported spending the social cash transfer on education for their children. The spending pattern on this outcome was mainly payment of school user fees; although primary education in Zambia is free, schools still charge such fees. In addition, parents still have to buy uniforms and learning materials for their schoolchildren. One of the participants had this to say: 'children are able to go to school because I am now able to pay for school requirements using the social cash transfer payments.' Others revealed that as a result of the social cash transfer support, their food intake had improved and their children no longer go to school 'on an empty stomach' because they were now food secure. This finding confirms previous studies by Andrews \& Kaufman (1999) who concluded that children's socioeconomic conditions affect their future because they impact directly on their right to education, which is a key determinant for a brighter future. Andrews and Kaufman argued that children growing up in poverty are not as healthy, intelligent, and confident as their counterparts from affluent families and less likely to record positive education outcomes (1999: 60-61). Similarly, Seidenfeld et al. (2013) found that social cash transfer programmes such as the child grant that was implemented in Kaputa, Kalabo, and Shan'ombo in Zambia had noticeable impact on education among children with less educated mothers compared but without significant impact on education among children with educated mothers (2013: 44). Their explanation for this was that educated mothers enrolled their children before they started receiving the cash grants, while less educated mothers used the child grant as a motivation to enroll their children in school. In addition, participants reported increased spending on school-related expenses such as user fees and school learning materials, which further indicates a positive impact for education for children generally, and further confirms the findings of Seidenfeld \& Handa (2011) who recorded a substantial impact of social cash transfers on school enrolment among the children of the age group from 6-16 (2011: 24). However, it should be noted that higher school enrolment and attendance rates for children from poor households do not necessarily translate into quality education. As Lomeli and others have shown, there is a tendency to assume that increased enrolment and attendance of children from social cash transfer recipient households automatically result in real education outcomes, without taking into account the quality of education such children are receiving (2008: 6; see also Schady et al., 2008). Real progress on education should be measured by the literacy rates and number of children completing a full course of primary education because these are the key indicators of the quality of universal primary education (UNDP, 2013b: 2).

As regards health and nutrition outcomes, 10 percent of participants revealed that they used the social cash transfers to pay for health services. One of the respondents reported that he bought a bicycle using the cash transfer, which he uses to access health facilities. The study further revealed an increased spending on food and nutrition including groceries. Seventy-six percent of research participants reported using the social cash transfer on food and other household groceries, which ultimately had positive outcomes for health. In addition, 10 percent of participants reported investing the social grant on livestock and agricultural investment. This, consequently, had positive impact on food security and livelihoods. This finding confirms the study findings by Seidenfeld et al. (2013) who noted less significant health outcomes of older children (aged 6-17) with regard to morbidity, treatment seeking, and chronic illness in the Zambian remote districts of Kaputa, Kalabo, and Shan'ombo. Generally, however, more people had a sense of wellbeing and felt more respected in community because of social cash transfer income status (IDS, 2014). The study further noted increased spending on food and nutrition including groceries. Seventy-six per cent of beneficiaries reported using cash transfers on food and other household groceries, which ultimately had positive health outcomes for children. A further 10 percent of beneficiaries reported investing the social grant on livestock and agricultural investment, which subsequently improved their food security and livelihoods. The other finding noted relating to this thematic area was lack of access to safe and clean water and sanitation in the study areas, which has implications on child health. It was evident that, being remote and underdeveloped, the areas covered by the study had no access to water and sanitation services. Participants revealed that they mitigate the acute shortage of safe and clean drinking water by boiling their drinking from shallow wells. This finding confirms similar observations made by the UK Department for International Development and others that over 6.5 million people in Zambia have no access to adequate sanitation (DFID, 2012; UNDP, 2013b).

\subsection{Sustainability of Social Cash Transfers}

So far as the sustainability and affordability of social cash transfers, all participants, except one, reported that the 
programme is sustainable and affordable. One of the key informants stated that the programme is sustainable and affordable because it is fully owned and largely funded by government. A perusal of the 2014 national budget revealed that the government had significantly increased funding towards social security, raising the allocation for social cash transfers from 25 percent in 2010, 2011, 2012 and 2013 to 70 per cent in 2014. Further, the pronouncements by the Minister of Finance show strong political support, which is a crucial step of making social cash transfers sustainable. For example, during the 2014 national budget address to the National Assembly the Minister of Finance showed strong political support for social cash transfers:

"In 2014, government's contribution to the social cash transfer scheme will be scaled up by over 700 percent in order to make a significant impact on reducing extreme poverty. ... I am cognizant of the successful piloting of social cash transfers in several districts across the country and their direct impact on reducing extreme poverty. Accordingly, I have decided to increase the allocation for this scheme from K72.1 million to K199.2 million in 2014."

Based on this, participants argued that considering that the allocation represented only one percent of the total national budget, participants argued social cash transfers are affordable. Affordability is based on the assumption that government and cooperating partners will continue to fund the programme in the foreseeable future. The budgetary allocation to the social cash transfer programme has increased exponentially since 2014 .

\subsection{Challenges of Social Cash Transfers}

The study noted a number of challenges continue to constrain effective implementation of social cash transfers in Zambia. Some of these have been discussed in the preceding section, but key among them are: financial sustainability, lack of capacity, negative perceptions of the social cash transfer programme, political interference, and programme size. Some participants especially beneficiaries were doubtful whether the government will continue to financially sustain the programme. Long-term financial sustainability of social cash transfers remains a major challenge not only in Zambia, but in many other developing countries because it anchors in the allocation of scare resources. Financial sustainability concerns the 'long-term financial viability of social protection programmes' (Wood, 2008). More importantly, policymakers such as finance ministers and economists are skeptical about the sustainability and affordability of social cash transfers and are concerned of the 'fiscal and especially political pressures once the programmes are

12014 Budget Address by Hon. Alexander B. Chikwanda, Minister of Finance, to the National Assembly, October 11, 2013. incorporated into the budgetary system' (Niño-Zarazúa et al., 2010).

Limited capacity to formulate, delivers, and evaluate social cash transfer programmes was another challenge. This is not unusual in developing countries particularly in sub-Saharan Africa (Niño-Zarazúa et al., 2010: 25-29). One of the key informants revealed that effective implementation of the social cash transfer programme in Zambia is constrained by lack of logistical, administrative and technical capacity, particularly at district level, to manage the social cash transfer programme. The participant pointed out that there was a great need to invest in information communication technologies and human resources. Other informants also reported that the lack of incentives and transport for community volunteers continue to undermine the effective implementation of the programme because volunteers are among key actors to the social cash transfer programme. They note that the management information system would fulfill several critical functions, such as the selection of beneficiary families, payments management, case management, base for the control and monitoring processes, selection of beneficiaries for other public policies, as well as identification of the various poverty dimensions and vulnerability (2010: 191-193).

It was also noted that skeptical policymakers raise the concern that social cash transfers create dependency and promote laziness among recipients. However, evidence by Samson (2009), Samson et al. (2004), Samson and Williams (2007), and Williams (2007), in the South African case, shows that workers in poor households who received social grants actively and extensively searched for and found employment more successfully than workers in comparably poor households that did not receive grants (2009: 46-47). In addition, in Malawi Chinsinga observed that recipients of social cash transfers made significant investments from the cash received although the evidence was anecdotal (2009: 20). Similarly, Samson (2009) also noted that social grants have the effect to 'mitigate social risk and relax liquidity constraints on poor households, encouraging migration and job search.'

Further, key informants explained that the targeting procedure associated with cash transfers was fraught with problems, which are rooted in the programme design and implementation. One of the informants revealed that the 10 percent inclusive model type of social cash transfers implemented in Monze was too restrictive and that a lot of eligible poor households had been excluded. Gaiha (2010) found similar challenges in terms of the design and implementation of similar poverty reduction programmes in India, where some well-off people were included on the list of beneficiaries of the programmes which otherwise was purely intended for the poor. The finding confirms the views of other writers who have argued that the targeting procedure for potential recipients in most countries has not always been perfect (Barriendos \& Hulme, 2013; 
Chinsinga, 2009; Wood, 2008).

The research also found that the social cash transfer programme is susceptible to abuse by politicians. Participants reported that politicians have realized the potential political impact of social cash transfers and are therefore making efforts to get fully involved in the management of social cash transfers in their constituencies for political reasons. This observation is valid, given the political dynamics that characterise most social protection programmes in Africa generally (Samson \& Williams, 2007: 2). For example, in Kenya, Uganda, and Botswana social cash transfer programmes were used as incentives to reward supporters of particular political candidates, and as a weapon to 'punish' those perceived to be supporting political opponents by excluding them from such interventions (Hickey, 2007: 3-4). But as Hickey (2007) notes, it is often authoritarian or semi-democratic regimes that tend to use social cash transfers 'to boost regime legitimacy and retain political power.'

In summary, the findings of this study demonstrate sufficient evidence that the social cash transfer programme in Zambia is financially sustainable, at least for the time being, and has sufficient political support. It is evident, going by the current political and economic environment in the country, that the social cash transfer programme has received the required political support as shown through increased budgetary allocations. This demonstrates financial commitment and ownership, which are critical to the sustainability of the social cash transfer programme in Zambia. The government's adoption of the National Social Protection Policy is another positive indicator. Whether this political support and commitment will be sustained for a longer term is not clear at present.

\section{Conclusions}

This study sought to assess the impact of social cash transfers on children's rights in Zambia and determine whether they are sustainable. Based on research findings, the study concludes that although social cash transfers in Zambia have helped increase access to education, health care and nutritional services among children from chronically poor households, their impact and sustainability remain contested. This is because reducing poverty and achieving higher outcomes for children require stronger political will and commitment to allocate scarce resources towards key social services (Sen 2000; Andrews \& Kaufman, 1999; Pupavac, 2009). In other words, social cash transfers cannot singularly eradicate poverty without the participation of other social sectors.

The study also found that the effective implementation of social cash transfers remains constrained by administrative, coordination, and capacity challenges, as well as lack of a defined long-term financial commitment. This situation is exacerbated by the fact that in Zambia, as in many other developing countries, different forms of politics shape different dimensions of social protection (Hickey, 2007). The forms of politics that lead to the conception and implementation of particular social protection programmes such as social cash transfers very often tend to be different from those that may be required to sustain such programmes and identify potential beneficiaries.

Based on these findings and analyses, the study recommends that to make social cash transfers in Zambia more impactful and sustainable, the government should, firstly, continue to increase budgetary allocations for social protection. This is the only practical way to sustain the social cash transfer programme, which has gained so much momentum. The government must also take full ownership of the cash transfer programme, while donors and other cooperating partners should move from focusing on technical assistance to addressing the political dimensions of pro-poor policy. Secondly, all social cash transfer programmes should be linked with other sectors for coherence, effectiveness, and resource leveraging. This ensures stronger protection of children's rights and coherence in the coordination of all child protection systems to create an enabling environment for children to enjoy long, healthy, and creative lives through increased access to essential social services. For this to happen, the government should take concrete steps to adopt laws and policies that reflect international human rights norms and standards. Thirdly, the design of social cash transfer programmes must facilitate the full participation of the recipients of cash transfers as actors, rather than as passive recipients. In this way, social cash transfers will preserve the empowering potential of social protection and subsequently transcend the 'dependency' or 'hand-out' culture with which cash transfers are associated, especially in low income countries (Hackey, 2007: 9). This would also help dispel the perception that social cash transfers are simply handouts or a form of charity. Fourthly, considering that employment creation is one of the most effective and sustainable ways of reducing poverty - as it raises household incomes and the fact that labour is the most abundant resource at the disposal of the poor as Jesuits in Zambia tell us - the government should create employment opportunities for young people. This can be done through economic expansion and provision of entrepreneurial resources. Fifthly, to address the administrative inefficiencies in the management of social protection programmes, government should come up with remedial measures such as setting up stronger institutional accountability for all the different social protection programmes not just social cash transfers. To actualize this, government and cooperating partners should invest in human capital development in information communication technology capacity development and automate all social cash transfer programmes.

In the final analysis, the study contends that to ensure a 
stronger institutional framework for effective implementation of social cash transfers so as to substantially reduce poverty, getting the politics of social protection right is more important than the initial technical design of social protection programmes (Niño-Zarazúa et al., 2010: 31-32). Thus, getting the support of key political actors and agencies who have a direct impact on, and are closely associated with, social protection programming is crucial to the success of any poverty reduction strategies such as social cash transfers.

\section{REFERENCES}

[1] Abel-Smith, B. \& Townsend, P. 1965. The Poor and the Poorest. London: Bell.

[2] Allen, T. \& Thomas, A. eds. 2000. Poverty and Development into the $21^{\text {St }}$ Century. New York: Oxford University Press.

[3] Alvesson, M. \& Sköldberg, K. 2000. Reflexive Methodology - New Vistas for Qualitative Research, London: SAGE.

[4] Andrews, A.B. \& Kaufman, N.H. 1999. Implementing the UN Convention on the Rights of the Child: A Standard of Living Adequate for Development. Westport, CT: Praeger Publishers.

[5] Anyangwe, C. 1997. 'The Zambian Constitution and the Principles of Constitutional Autochthony and Supremacy', Zambia Law Journal, 29: 1-32.

[6] APF. 2012. International Human Rights and the International Human Rights System: A Manual for National Human Rights Institutions. http://www.asiapacificforum.ne $\mathrm{t}$, accessed 01.05.2015.

[7] Archard, D. 2004. Children: Rights and Childhood. (2nd edition) Oxon: Routledge.

[8] AU. 2013. African Charter on the Rights and Welfare of the Child, http://www.au.int/en/sites/default/files/Charter_En_Africa n_Charter_on_the_Rights_and_Wlefare_of_the_Child_Ad disAbaba_July1990.pdf, accessed: 1.11.2013.

[9] Balaam, D.N. \& M. Veseth. 2001. Introduction to International Political Economy, New Jersey: Prentice Hall

[10] Barrientos, A. \& Hulme, D. 2013. 'Social Protection for the poor and poorest: An Introduction', in A. Barrientos \& D. Hulme. eds. Social Protection for the Poor and Poorest: Concepts, Policies and Politics. Houndmills: Palgrave.

[11] Baulch, B. \& J. Hoddinott. 2000. 'Economic mobility and poverty dynamics in developing countries', The Journal of Development Studies, 36(6), pp. 1-24.

[12] Becker, S., Bryman, A. \& Ferguson, H. 2012. Understanding Research for Social Policy and Social Work. (2nd edition) Bristol: Polity Press.

[13] Blakemore, K. \& Griggs, E. 2007. Social Policy: An
Introduction. (3rd edition) Yorkshire: Open University Press.

[14] Bryman, A. 2012. Social Research Methods, $4^{\text {th }}$ edition, New York: Oxford University Press.

[15] Bryman, A. 1988. Quantity and Quality in Social Research, London: Unwin Hyman Ltd.

[16] Bullock, A. and S. Trombley. (eds.) 1999. The New Fontana Dictionary of Modern Thought, Third edition. London: W .W. Norton and Company Ltd.

[17] Burns, R.B. 2000 Introduction to Research: Methods, Perth: Pearson.

[18] Chanda, A.W. 2001. 'The role of lower courts in domestic implementation of Human Rights,' Zambia Law Journal, 32: 1-17.

[19] Chinsinga, B. 2009. Political Economy of Cash Transfers in Malawi: A Report prepared for the Overseas Development Institute, London. http://www.odi.org.uk/sites/odi.org.uk/fi les/odi-assets/publications-opinion-files/5753.pdf, accessed 12.03.2014.

[20] CIDA. 2010. Canada's Aid Effectiveness Agenda: Focusing on Results. http://www.acdi-cida.gc.ca/acdi-cida/ACDI-CI DA.nsf/eng/FRA-825105226-KFT, accessed: 14.03.14.

[21] Clapham, A. 2006. Human Rights Obligations of Non-State Actors. Oxford: Oxford University Press.

[22] Clough, P. 2012. A Student's Guide to Methodology, 3rd edition, London: Sage.

[23] Cohen, L. M. Lawrence, \& Morrison, K. 2007. Research Methods in Education, 5th edition, New York: Routledge. http://research-srttu.wikispaces.com/file/view/Research+M ethods+in+Education_ertu.pdf, accessed: 22.03.14.

[24] Conway, T., de Haan, A. \& Norton, A. 2000. Social Protection: New Directions of Donor Agencies. London: Department for International Development.

[25] Covarrubias, K., Benjamin, D. \& Winters, P. 2012. From Protection to Production: Productive Impacts of the Malawi Social Cash Transfer Scheme. http://www.cpc.unc.edu/projects/transfer/countries/malawi, accessed 12.03.2014.

[26] Creswell, J. W. 2007 Qualitative Inquiry and Research Design: Choosing Among Five Approaches, Thousand Oaks: SAGE.

[27] CSO. 2011. Zambia: 2010 Census of Population and Housing. Lusaka: Central Statistical Office.

[28] CSO. 2012. Living Conditions Monitoring Survey Report 2006/2010. Lusaka: Central Statistical Office.

[29] CSO. 2009. Zambia Demographic and Health Survey 2007. Lusaka: Central Statistical Office.

[30] Deacon, B. 1999. 'Social policy in a global context'. In: Hurrell, A. \& Woods, N. eds. Inequality, Globalization, and World Politics. New York: Oxford University Press.

[31] Dean, H. 2002. Welfare Rights and Social Policy. Essex: Pearson. DFID. 2012. DFID's Programme in Zambia, Fifth Report of Session 2012-13. London: UK Department for International Development. 
[32] Donnison, D. 2001. 'The changing face of poverty', in M. May, R. Page, E. Brunsdon. eds. Understanding Social Problems: Issues in Social Policy. Oxford: Blackwell Publishers.

[33] Dreher, A. 2009. 'IMF conditionality: Theory and evidence', Public Choice, 1, 2: 233-267.

[34] Dunne, T. and M. Hanson. 2009. 'Human Rights in International Relations', in Goodhart, M. (ed.), (2009) Human Rights: Politics and Practice, New York: Oxford University Press.

[35] Esping-Andersen, G. 1990. The three worlds of welfare capitalism, Cambridge: Polity Press.

[36] Gaiha, R. 2010. 'Do anti-poverty programmes reach the rural poor in India?', Oxford Development Studies, 28, 1: 71-95.

[37] Gaiha, R. \& Imai, K. 2002. 'Rural Public Works and Poverty Alleviation - the case of the employment guarantee scheme in Maharashtra', International Review of Applied Economics, 16(2), pp. 131-151.Routledge. http://www.tan dfonline.com/doi/abs/10.1080/02692170110118876, accessed: 11.07.2014.

[38] Gareth, J. A. 2005. 'Children and development: rights, globalization and poverty', Progressin development studies, 5(4), pp. 336-342. Available at: http://eprints.lse.ac.uk/169 71/, accessed: 10.03.2014.

[39] Genugten, W. J. M. van \& Perez-Bustillo, C. (eds.). 2001. The Poverty of rights: Human Rights and the Eradication of Poverty, London: Zed Books.

[40] George, V. 2004. 'Globalisation and poverty', in V. George \& R.M. Page. eds. Global Social Problems. Cambridge: Polity Press.

[41] Goodhart, M., (2009) Human Rights: Politics and Practice, Oxford: Oxford University Press

[42] Hailu, D. \& Veras Soares, F. 2008. Cash Transfers in Africa and Latin America: An Overview. International Poverty Centre.

[43] Harrington, L.V. 2011. Mexico's Conditional Cash Transfer Program: Promises, Predictions and Realities. (Masters) Ohio: The Ohio State University.

[44] Hickey, S. 2007. Conceptualising the Politics of Social Protection in Africa, BWPI Working Paper 4. Manchester: Brooks World Poverty Institute.

[45] HMSCTS. 2013. Harmonised Manual on Social Cash Transfer Scheme. Lusaka: Ministry of Community Development, Mother and Child Health.

[46] Holzmann, R. \& Jorgensen, S. 2000. Social Risk Management: A new conceptual framework for Social Protection, and beyond, Social Protection Discussion Paper No. 0006.http://info.worldbank.org/etools/docs/libra ry/80363/conceptfram.pdf, accessed 05/08/2015.

[47] Holzmann, R. \& Jorgensen, S. 1999. 'Social protection as social risk management: conceptual underpinnings for the social protection sector strategy paper', Journal of International Development, 11, 7: 1005-1027.

[48] Hubbard, G. 2011. Cash Transfers Provide Social
Protection to Zambia's most vulnerable families: Breaking the Cycle of Poverty.http://www.unicef.org/infobycountry/ zambia 59436.html, accessed 20.03.2014.

[49] ILO. 2008. Zambia: Social Protection Expenditure and Performance Review and Social Budget. Washington, D.C.: International Labour Office.

[50] ILO. 2001. Social Security: A New Consensus. Geneva: International Labour Office.

[51] Imran, M., M. Sulaiman, \& Rabbani, M. 2008. Crafting a Graduation Pathway for the Ultra Poor: Lessons and Evidence from a BRAC programme. Working Paper March 2008 No. 109. http://www.chronicpoverty.org/uploads/pub lication_files/WP109_Martin.pdf, accessed: 20.03.14.

[52] Jahan, S. 2004. Human Rights-Based Approach to Poverty Reduction - Analytical Linkages, Practical Work and UNDP. http://www.cihc.org/members/resource library pd fs/2_Law_and_Protection/2_6_Rights_based_Assistance/ HR approach to Poverty_Reduction.p.pdf, accessed 26.07 . 2013.

[53] JCTR. 2011. Survey on Employment Generating Policies and Strategies in Zambia. Lusaka: Jesuit Centre for Theological Reflection.

[54] Kalin, W. \& Kunzlin, J. 2009. The Law of International Human Rights Protection. Oxford: Oxford University Press.

[55] Kankwanda, M, Greogoire, L., Legros, H., \& Ouedraogo, H. 2000. Poverty Eradication: Where Stands Africa? London: Economical.

[56] Kochar, A. 2008. 'The Effectiveness of India's Anti-Poverty Programmes', The Journal of Development Studies, 44(9), pp.1289-1308.

[57] Kokaz, N. 2007. 'Institutions for Global Justice', Canadian Journal of Philosophy, Supplementary, 31 pp. 65-107.

[58] Lekezwa, B.I. 2011. The Impact of Social Grants as Anti-Poverty Policy Instruments inSouth Africa: an Analysis Using Household Theory to Determine Intra-Household Allocation of Unearned Income. Masters of Commerce in Economics Thesis, University of Stellenbosch: Stellenbosch.

[59] Lund, F., Noble, M., Barnes, H. \& Wright, G. 2008. Is there a rationale for conditional cash transfers for children in South Africa? Working Paper No 53. http://sds.ukzn.ac.za/files/WP\%2053\%20web.pdf, accessed 15.03.2014.

[60] Makgetha, N.S. 1986. 'Theoretical and practical implications of IMF conditionality in Zambia', Journal of Modern African Studies, 24, 3: 395-422.

[61] Mason, J. 2002. Qualitative Researching, $2^{\text {nd }}$ edition, London: SAGE

[62] McCord, A. 2009. Cash Transfers: Affordability and Sustainability, Project Briefing No. 30. London: Overseas Development Institute.

[63] McLean, I. \& McMillan, A. eds. 1996. Oxford Concise Dictionary of Politics. Oxford: Oxford University Press.

[64] MOF. 2006. Zambia Vision 2030. Lusaka: Cabinet Office. 
[65] MOF. 1992. New Economic Recovery Programme: Economic and Financial Policy Framework 1992-1994. Lusaka: Ministry of Finance, Zambia.

[66] Mwale, S. 2004. Zambia's Economic, Social and Cultural Rights: Why should they be in the new Constitution? Research Report. Lusaka: Jesuit Centre for Theological Reflection.

[67] Ncube, P.D., Sakala, M. \& Ndulo, M. 1987. 'The International Monetary Fund and the Zambian economy'. In: Havnevik, K. ed. The IMF and World Bank Conditionality and Alternatives. Uppsala: Scandinavian Institute of African Studies.

[68] Neuman, L. 2003. Social Research Methods. Qualitative and Quantitative Approaches, London: Pearson Education

[69] Niño-Zarazúa, M., Barrientos, A., Hulme, D. \& Hickey, S. 2010. Social Protection in Sub-Saharan Africa: Getting the Politics Right. Manchester: Brooks World Poverty Institute.

[70] NSPP. 2014. National Social Protection Policy, MCDMCH Headquarters, Lusaka.

[71] Nyamu-Musembi, C. \& Cornwall, A. 2004. What is the 'Rights-Based Approach' all about? Perspectives from International Development Agencies, IDS Working Paper 234. Sussex: Institute of Development Studies.

[72] Oakley, A. \& Williams, A.S. 1994. The Politics of the Welfare State. London: University College London.

[73] ODI. 1999. What can we do with a rights-based approach to development? Oversees Development Institute, Briefing Paper 1999 (3), Portland House: London

[74] OHCHR. 2015. What are human rights? http://www.ohchr.org/EN/Issues/Pages/WhatareHumanRig hts.aspx, accessed 05.08.2015

[75] OHCHR. 2012. Convention on the Rights of the Child. http://www.ohchr.org/EN/ProfessionalInterest/Pages/CRC. aspx, accessed: 6/11/13.

[76] Parlett, M. 1975 'Evaluating innovations in teaching', in Greenwald, J. and R. West, (eds.), Curriculum Design, London: Croom Helm.

[77] Punch, K. F. 2006. Developing Effective Research Proposals, London: SAGE.

[78] Pupavac, V. 2009. 'Children's human rights advocacy', in M. Goodhart. ed. Human Rights: Politics and Practice. New York: Oxford University Press.

[79] Ressler, P. 2008. The Social Impact of Cash Transfers: A study of the impact of cash transfers on social networks of Kenyan households participating in cash transfer programs.

http://ebrary.ifpri.org/cdm/ref/collection/p15738coll2/id/31 489, accessed 05/08/2015.

[80] Ressler, P. 2008. The Social Impact of Cash Transfers: A study of the impact of cash transfers on social networks of Kenyan households participating in cash transfer programs.

http://ebrary.ifpri.org/cdm/ref/collection/p15738coll2/id/31 489, accessed 05/08/2015.

[81] Rawls, J. 1999. A Theory of Justice. (Revised Edition)
Oxford: Oxford University Press.

[82] Richter, L.M. 2009. "Can and should cash transfers be linked to social welfare?" Vulnerable Children and Youth Studies, 4: 1, pp. 72-76. https://www.tandfonline.com, accessed 09.07.2018

[83] Rowlingston, K. 2001. 'Child poverty and the policy response', in M. May, R. Page \& E. Brunsdon. eds. Understanding Social Problems: Issues in Social Policy.

[84] Saasa, O.S. 1996. Policy Reforms and Structural Adjustment in Zambia: The Case of Agriculture and Trade, Technical Paper No. 35. U.S. Agency for International Development.

[85] Samson, M. 2009. Social Cash Transfers and Pro-Poor Growth. Organisation for Economic Co-operation and Development.

[86] Samson, M., van Niekerk, I. \& Mac Quene, K. 2010. Designing and Implementing Social Transfer Programmes, Second Edition. South Africa: Economic Policy Research Institute.

[87] Sanfilippo, M., de Neubourg, C. \& Martorano, B. 2012. The Impact of Social Protection on Children: A Review of the Literature, Office of Research Working Paper WP-2012-06. Florence: UNICEF Office of Research.

[88] Sarantakos, S. 2005. Social Research, New York: Palgrave Macmillan.

[89] Schady, N. \& Araujo, M.C. 2008. Cash Transfers, Conditions, and School Enrollment in Ecuador. http://www.cid.harvard.edu/Economia/papers/Bogota\%202 007/Schady-Araujo-December06.pdf, accessed 14.07.2014.

[90] Schubert, B. 2005. Social Cash Transfers - Reaching the Poorest: A Contribution to the international Debate Based on Experience in Zambia. http://www2.gtz.de/dokumente/ bib/05-0542.pdf, accessed 13.03.2014.

[91] Schubert, B. 2004. The Pilot Social Cash Transfer Scheme: Kalomo District Zambia. http://www.sed.manchester.ac.uk /research/events/conferences/documents/Social\%20Protect ion\%20Papers/Schubert.pdf, accessed 12.03.2014.

[92] Schubert, B. \& Slater, R. 2006. 'Social cash transfers in low-income African countries: Conditional or unconditional?', in Development Policy Review, 24, 5: 571-578.

[93] Seidenfeld, D. \& Handa, S. 2011. Results of the Three Year Impact Evaluation of Zambia's Cash Transfer Program in Monze District Final Report. Washington, D.C.: American Institute for Research.

[94] Seidenfeld, D., Handa, S. \& Tembo, G. 2013. Zambia's Child Grant Program: 24-month impact Report. Washington, D.C.: American Institutes for Research.

[95] Sen, A. (2004) Elements of a theory of human Rights. Philosophy \& Public Affairs. 32(4) pp. 315-356.

[96] Seshamani. V. 2005. The same old wine in the same old bottle? Content, process and donor conditionalities of the PRSP, Paper presented at the 'Political Dimensions of Poverty Reduction - the Case of Zambia' conference organised by the University of Zambia and the University of Duisburg-Essen, Germany, 9-11 March 2005. 
http://www.sarpn.org/documents/d0001178/P1307-Sesham ani_PRSP_March_2005.pdf, accessed 05.08.2015.

[97] Seshamani, V. 2002. The PRSP Process in Zambia. Paper presented at the 2nd meeting of the African Learning Group on the PRSP. Brussels 18-21 November 2002. http://www.un eca.org/prsp/docs/prsp_final/zambia.pdf,accessed 05.08.2015.

[98] Sorensen, J. 1999. Introduction to International Relations, Oxford: Oxford University Press.

[99] Tembo, G. and N. Freeland. 2009. Social Cash Transfers in Zambia: What Is Their Impact? The International Policy Centre for Inclusive Growth, No. 91. http://www.ipc-undp. org/pub/IPCOnePager91.pdf, accessed: 12.03.14.

[100] Townsend, P. 1979. Poverty in the United Kingdom. Harmondsworth: Penguin Books.

[101] UNDP. 2014c. Human Development Index (HDI). http://hdr.undp.org/en/content/human-development-indexhdi, accessed 04.08.2014.

[102] UNDP. 2014b. Post-2015 Sustainable Development Agenda. http://www.undp.org/content/undp/en/home/mdgoverview/ post-2015-development-agenda/, accessed 04.08.2014.

[103] UNDP. 2014a. Human Development Report 2014. New York: United Nations Development Programme.

[104] UNDP. 2013b. Millennium Development Goals: Progress Report Zambia 2013. New York: United Nations Development Programme.

[105] UNDP. 2013a. Progress Report 2013 of Delivering as One Under the United Nations Development Assistance Framework 2011-2015. Lusaka: United Nations Development Programme.

[106] UNDP. 2004. Social Protection in Africa: A Review of Potential Contribution and Impact on Poverty Reduction. South Africa: United Nations Development Programme.

[107] UNICEF. 2014b. Social Protection. Lusaka: United Nations Children's Fund.

[108] UNICEF. 2014a. UNICEF Annual Report 2013. New York: United Nations Children's Fund.

\footnotetext{
i This paper draws upon the findings of a research study completed in May-August 2014 in Lusaka and Monze in Zambia. I wish to thank the Sacred Heart Foundation who made it possible for me to undertake this research, Dr. Gregory Kent and staff in the Department of Social Sciences at the University of Roehampton, and all participants who took part in the research.
}

[109] UNICEF. 2012. Zambia Annual Report 2012. Lusaka: United Nations Children's Fund.

[110] van der Berg S., M. Louw and L. du Toit. 2007. Poverty trends since the transition: What we know, Stellenbosch Economic Working Papers: 19/09. http://www.npc.gov.za/ MediaLib/Downloads/Home/Tabs/Diagnostic/Economy2/ Poverty $\% 20$ trends $\% 20$ since $\% 20$ the $\% 20$ transition.pdf, accessed: 15.03.14.

[111] Van der Berg S., R. Burger, R. Burger, M. Louw and D. Yu. 2005. Trends in poverty and inequality since the political transition, Stellenbosch Economic Working Papers No: $1 /$ 2005.

http://www.ber.ac.za/downloads/2005/working_papers/WP -01-2005.pdf, accessed: 15.03.14.

[112] Walliman, N., (2011) Your Research Project: Designing and Planning Your Work, $3^{\text {rd }}$ Edition, London: SAGE

[113] Wood, D. 2008. Social Protection and Children's Rights in Zambia. Lusaka: Jesuit Centre for Theological Reflection.

[114] World Bank. 2014. Zambia: Overview. http://www.worldbank.org/en/country/zambia/overview\#1, accessed 04.08.2015.

[115] World Bank. 2012. Zambia Economic Brief: Recent Economic Developments and the State of Basic Human Opportunities for Children. Washington, D.C.: The World Bank.

[116] World Bank. 2004. Zambia - Poverty Reduction Strategy Paper (PRSP) Annual Progress Report and Joint Staff Assessment. Washington, D.C.: World Bank.

[117] World Bank. 2000. World Report: Attacking Poverty. New York: Oxford University Press.

[118] World Bank. 1990. World Development Report 1990. New York: Oxford University Press.

[119] Yiyugsah, B. 2010. A Decade of Poverty Reduction Strategy Papers and the Paradox of Development Cooperation: A Comparative case study of Ghana and Zambia, Central European University. http://www.etd.ceu. hu/2010/yiyugsah benedict.pdf, accessed 05/08/2015. 